\title{
PENGEMBANGAN MULTIMEDIA INTERAKTIF BERBASIS AUTOPLAY SEBAGAI MEDIA PROMOSI KESEHATAN TENTANG KESEHATAN GIGI DAN MULUT PADA SISWA KELAS V SDN PERCOBAAN 02 KOTA MALANG
}

\author{
Heri Setiawan \\ Sapto Adi \\ Nurnaningsih Herya Ulfah \\ Fakultas Ilmu Keolahragaan Universitas Negeri Malang \\ E-mail: herisetiawan710@gmail.com
}

\begin{abstract}
Abstrak: Penelitian ini bertujuan untuk menghasilkan media promosi kesehatan berupa multimedia interaktif berbasis autoplay di SDN Percobaan 02 Kota Malang. Metode penelitian yang digunakan adalah penelitian dan pengembangan yang telah disesuaikan dengan kemampuan peneliti. Teknik pengumpulan data menggunakan analisis kebutuhan dan angket penilaian yang diberikan untuk siswa dan ahli media serta ahli materi. Teknik analisis yang digunakan adalah analisis deskriptif sesuai prosedur pengembangan. Kesimpulan dari hasil penelitian pengembangan ini adalah multimedia sangat layak atau valid digunakan bagi siswa kelas 5 SDN Percobaan 02 Kota Malang. Hasil produk akhir multimedia interaktif tentang kesehatan gigi dan mulut belum diketahui seberapa besar pengaruhnya terdapap peningkatan pengetahuan siswa, maka perlu dilakukan penelitian lanjutan terkait hal tersebut.
\end{abstract}

Kata kunci: multimedia, interaktif, autoplay, kesehatan gigi dan mulut

\begin{abstract}
This study aims to produce health promotion media in the form of interactive multimedia based on autoplay in SDN Percobaan 02 Kota Malang. The research method used is research and development that has been adapted to the ability of researchers. Data collection techniques use needs analysis and assessment questionnaire given to students and media experts and material experts. The analysis technique used is descriptive analysis according to the development procedure. The conclusion of the results of this development research is a very feasible or valid multimedia used for 5th grade students SDN Percobaan 02 Kota Malang. The result of interactive multimedia product about dental and oral health is not known how much influence the student's knowledge increase, hence need to do further research related to that matter.
\end{abstract}

Keywords: multimedia, interactive, autoplay, oral and dental health

Pendidikan kesehatan gigi dan mulut merupakan segala upaya atau aktivitas seseorang dalam menjaga dan meningkatkan kesadaran akan kesehatan gigi dan mulut (Andriany, 2016). Larasati (2012) menjelaskan penyakit gigi dapat berupa kerusakan gigi dan pe-nyakit gusi. Penyebab dasar kerusakan gigi dan penyakit gusi adalah kebersihan mulut yang buruk seperti diakibatkan oleh merokok, kekurangan vitamin, dan makanan manis dan lengket. Menurut
Darmawan (2007) masalah pada gigi terletak pada kurangnya kesadaran tentang kesehatan gigi dan mulut itu sendiri.

Berdasarkan penelitian Gayatri dan Madianto (2016) melalu gambaran status karies gigi Sekolah Dasar Kota Malang yang dilakukan di SDN Perco-baan 02 dan SDN Kauman 02 Kota Malang dengan jumlah sampel 284 sis-wa, dilakukan pemeriksaan komponen nilai decayed, missing, dan filled. Nilai 
total yang didapatkan kerusakan gigi permanen akibat karies sebanyak 1025 , gigi yang hilang akibat karies sebanyak 591, dan gigi yang ditambal akibat karies adalah sebanyak 18. Dari hasil

pemeriksaan tersebut selanjutnya dianalisa menggunakan rumus indkes def-t/DMF-T menurut World Health Organization (WHO). Diketahui indeks total diperoleh angka 5,75, yang menyatakan tergolong tinggi di rentang

4,5-6,5. Angka tersebut mengindikasikan prevalensi karies gigi siswa Sekolah Dasar Kota Malang adalah tinggi.

Berdasarkan observasi peneliti dan penelitian Gayatri dan Mardianto (2016), kesehatan gigi dan mulut yang buruk terjadi karena anak lebih banyak makan makanan dan minuman yang menyebabkan gigi berlubang (karies), seperti makanan mengandung gula dan lengket serta jarang membersihkannya. Selain itu tingkat kesadaran untuk menjaga kesehatan gigi dan mulut masih tergolong rendah. Sementara itu peneliti juga melalukan observasi pendahuluan pada sekolah SDN Percobaan 02 Kota Malang didapatkan usia 10-11 tahun yang rata-rata duduk di kelas 5 sebanyak $78,1 \%$ siswa tidak menyikat gigi saat sebelum tidur dan $85,5 \%$ rata-rata pernah mengalami gigi berlubang dan tidak mengetahui bagaimana menjaga kesehatan gigi dan mulut yang benar.

Berdasarkan permasalahan di atas peneliti ingin melakukan edukasi kesehatan gigi dan mulut berupa

promosi kesehatan. Menurut Notoatmodjo (2012) dalam proses promosi kesehatan di-perlukan media untuk membantu dalam menyampaikan pesan atau isi dari promosi kesehatan. Pemberian pendidikan kesehatan akan terlihat menarik jika disampaikan dengan media yang menarik pula (Pratiwi, dkk. 2015). Menurut Putra, dkk (2015) bahwa pembelajaran yang cocok dalam perkembangan teknologi di dunia pendidikan adalah menggunakan media pembelajaran interaktif salah satunya berbasis Autoplay. menurut Rizqi (2015) pemberian multimedia interaktif berbasis Autoplay mampu meningkatkan pemahaman terhadap materi yang diberikan selain itu juga menawarkan penguasaan materi, pemahaman, dan gambar-gambar menarik yang membuat siswa tertarik pada materi yang diberikan dibandingkan pembelajaran secara konvensional.

Menurut hasil wawancara bebas dengan salah satu guru kelas 5 multimedia interaktif ini dapat menjadi media promosi pertama di sekolah ini sebab belum ada media serupa yang

pernah memberikan penyuluhan menggunakan multimedia interaktif

berbasis Autoplay. Selain itu pengembangan multimedia interaktif ini menjadi langkah pertama dalam upaya menjaga kesehatan gigi dan mulut serta menjadi sumber belajar siswa di SDN Percobaan 02 maupun dirumah masingmasing siswa.

Berdasarkan paparan latar belakang tersebut peneliti melakukan penelitian

dan pengembangan multimedia interaktif berbasis Autoplay yang digunakan sebagai media promosi kesehatan tentang kesehatan gigi dan mulut pada sasaran siswa kelas 5 di SDN Percobaan 02 Kota Malang.

Penelitian dan pengembangan ini bertujuan untuk menghasilkan sebuah media promosi kesehatan berupa multimedia interaktif tentang kesehatan gigi dan mulut bagi siswa kelas 5 SDN Percobaan 02 Kota Malang.

Promosi kesehatan dalam arti pendidkan merupakan segala upaya yang direncanakan untuk mempengaruhi orang lain, baik individu, kelompok, atau masyarakat sehingga mereka dapat menolong dirinya sendiri dan mampu meningkatkan derajat kesehatan dirinya (Notoatmodjo, 2012). 
Dalam proses promosi kesehatan diperlukan media untuk membantu dalam menyampaikan pesan kesehatan. Media adalah suatu alat yang digunakan oleh petugas kesehatan dalam menyampaikan bahan, materi, dan pesan ke-sehatan untuk membantu dan memperagakan sesuatu di dalam proses pro-mosi kesehatan (Notoatmodjo, 2012). Pemilihan media promosi kesehatan harus didasarkan pada selera sasaran, memberi dampak yang luas, dan disampaikan dengan menarik (Komala, 2014).

Multimedia interaktif adalah alat yang dapat menciptakan penyuluhan interaktif yang mengkombinasikan teks, gambar, animasi, audio, dan gambar video. Menurut Sucipta (dalam Azizi, 2015) dalam menciptakan multimedia interaktif dalam pembelajaran harus memperhatikan beberapa hal, yakni: a) memiliki lebih dari satu media yang konvergen, seperti menggabungkan unsur audio dan visual, b) bersifat interaktif, dalam pengertian memiliki kemampuan untuk mengakomodasi respon pengguna, c) bersifat mandiri atau memberi kemudahan kepada pengguna.

Sementara itu menurut Khotimah (2015) mengemukakan bahwa multimedia harus ada beberapa komponen jika ingin dikatakan multimedia, diantaranya: a) harus ada komputer yang dapat berinteraksi dengan kita, b) harus ada link yang terhubung, c) harus ada alat navigasi yang memandu kita untuk membuka suatu informasi, d) menyediakan tempat bagi kita untuk mengumpulkan, memproses dan mengkomunikasikan informasi dan ide kita sendiri.

Materi kesehatan gigi dan mulut dalam multimedia interaktif harus kerjasama dengan pihak yang bersangkutan agar pesan yang akan disampaikan lebih terkonsep (Dwiyogo, 2013). Selain itu Dwiyogo juga menyebutkan beberapa pertimbangan dalam membuat multimedia interaktif agar efektif, antara lain: a) membuat kepastian materi yang ditampilkan menampilkan audio, visual, dan animasi yang sesuai dengan materi, b) teks yang ditampilkan dalam materi mengiterpretasikan gambar dan pemikiran yang sederhana, c) tampilan multimedia harus mengalir sehingga siswa dapat mengikuti dengan mudah, d) memberikan musik, gambar, animasi, video untuk menarik perhatian dan menghindari kebosanan siswa dalam belajar.

Siswa usia kelas 5 sekolah dasar pada umumnya sudah berusia 10-11 tahun, dalam usia ini anak sudah mampu berpikir abstrak dan memperkirakan apa yang akan terjadi (Sunarto, 2008). Piaget (dalam Hidayah, 2012) menjelaskan dalam perkembangan kognitif anak beradaptasi dengan menginterpretasikan objek dan kejadian di sekitarnya. Hidayah (2012) juga menambahkan pada usia 11 tahun anak sudah memasuki pada tahap operasional konkret, artinya mampu berpikir secara logika. Demikian menurut Sujiono (dalam Kha-dijah, 2016) menambahkan bahwa kemampuan kognitif ini dapat dikembangkan melalui media pembelajaran dengan tujuan merangsang anak melakukan kegiatan berpikir, perhatian, minat dan mengembangkan imajinasi anak

Penyebab dasar dari kerusakan gigi dan penyakit gusi adalah kebersihan mulut yang buruk (Larasati, 2012). Menurut Darmawan (2007) penyebab utama dari penyakit gigi adalah gaya hidup, diantaranya: a) membersihkan gigi de-ngan cara yang salah sehingga terluka, b) jarang membersihkan gigi hingga kuman hinggap di gigi, c) mengkonsumsi makanan dan minuman dengan cara salah, misal mengunyah makanan terlalu keras atau minum susu terlalu panas, d) mengkonsumsi 
makanan yang kurang baik seperti mengandung gula dan asam; e) merokok, f) minum minuman yang mengandung alkohol.

Mofidi, dkk (2009) mengemukakan ada beberapa strategi untuk mengubah kebiasaan menjaga kesehatan gigi dan mulut yang kurang baik, antara lain: a) memberikan promosi kesehatan gigi dan mulut di dalam kelas, b)

memberikan pendidikan motivasi kepada orang tua untuk mengambil peran aktif terhadap kesehatan anaknya,

c) menjalin kerjasama dengan kelompok tertentu untuk memastikan anakanaknya memiliki akses kesehatan gigi dan mulut.

Sementara itu menurut Malik (2008) ada beberapa cara untuk memelihara kesehatan gigi dan mulut yang baik, yaitu: a) diet makanan yang kita konsumsi seperti makanan manis, lengket, minuman panas dan lain sebagainya, b) menyikat gigi yang benar, artinya jangan sampai merusak struktur gigi, c) penambalan gigi terhadap gigi berlubang dilakukan sejak dini dengan melakukan kunjungan ke dokter gigi, d) melakukan pencabutan gigi apabila gigi tersebut sudah tidak dapat lagi dipertahankan dan menjadi penyebab infeksi di dalam mulut, e) kontrol enam bulan sekali kepada dokter gigi, hal ini guna mengetahui gigi dan mulut kita tidak bermasalah.

\section{METODE}

Model yang digunakan dalam penelitian dan pengembangan ini adalah model prosedural. Model prosedural adalah model yang bersifat deskriptif dan menggariskan pada langkah-langkah pengembangan sesuai kebutuhan peneliti (Wiladatika, 2014).

Penelitian dan pengembangan ini menggunakan metode $R \& D$ menurut
Sugiyono (2014) untuk menghasil-kan sebuah produk baru dengan langkahlangkah pengembangan sebagai berikut: 1) potensi dan masalah, 2) pengumpulan data, 3) desain produk, 4) validasi desain produk, 5) revisi desain produk, 6) uji coba kelompok kecil, 7) revisi produk,

8) uji coba kelompok besar, 9) revisi produk, 10) produksi akhir.

Subjek coba dalam penelitian dan pengembangan ini adalah 8 siswa pada uji coba kelompok kecil dan 20 siswa pada uji coba kelompok besar. Sedangkan juga ada penilaian guru, ahli materi dan ahli media untuk memberi masukan sebagai perbaikan media selanjutnya.

Jenis data yang dihasilkan pada penelitian pengembangan ini adalah data kualitatif dan data kuantitatif yang diperoleh melalui proses validasi oleh ahli materi, ahli media, dan pengguna (guru). Instrumen yang digunakan adalah angket untuk penilaian dengan skala 1-4 mulai sangat baik, baik, kurang baik, tidak baik. Data kualitatif berupa saran yang diberikan oleh ahli media, ahli materi dan juga pengguna (guru) yang dituliskan di angket yang sudah disediakan.

Data kualitatif ini dianalisis dengan menyimpulkan saran dan masukan dari ahli kemudian dikumpulkan dan dijadikan bahan perbaikan multimedia. Sedangkan data kuantitatif dari hasil penilaian siswa, pengguna (guru), ahli materi dan media dengan menggunakan ru-mus yang mengacu pada acuan intrepretasi menurut Sa'dun Akbar (2013) sebagai berikut. $\mathrm{H}$ ah $=\mathrm{Tsh}^{\mathrm{Tse}} \times 100 \%$ 
Tabel 1. Penilaian Kelayakan

\begin{tabular}{lcc}
\hline Presentase & Interpretasi & keterangan \\
\hline $81 \%-100 \%$ & Sangat layak & Digunakan tanpa revisi \\
Dapat digunakan dengan \\
revisi kecil
\end{tabular}

Sumber: Sa'dun Akbar (2013:82)

Tabel 2. Penilaian Ahli Materi

\begin{tabular}{lcl}
\hline \multicolumn{1}{c}{ Aspek } & $\%$ & Keterangan \\
\hline Kejelasan judul halaman awal & $100 \%$ & Sangat layak \\
Kelengkapan materi & $75 \%$ & Layak \\
Kebermanfaatan materi & $100 \%$ & Sangat layak \\
Uraian isi materi & $75 \%$ & Layak \\
Bahasa yang digunakan komunikatif & $100 \%$ & Sangat layak \\
Kesesuaian bahasa & $100 \%$ & Sangat layak \\
Kesesuaian materi & $100 \%$ & Sangat layak \\
Materi dapat dipahami mudah & $100 \%$ & Sangat layak \\
Kesesuaian ilustrasi dengan materi & $100 \%$ & Sangat layak \\
Kelogisan dan keruntutan materi & $100 \%$ & Sangat layak \\
Kelayakan materi sebagai sumber & $100 \%$ & Sangat layak \\
pengetahuan & & \\
Ketepatan penggunaan contoh video & $100 \%$ & Sangat layak \\
dengan materi & & \\
\hline
\end{tabular}

\section{HASIL}

\section{Hasil Validasi Ahli Materi}

Pada tahap validasi ahli materi dilakukan oleh salah satu dosen ilmu

kese-hatan masyarakat yang berkompeten di bidangnya, dengan hasil penilaian yang dapat dilihat pada tabel 2 .

Ahli materi juga memberikan saran perbaikan pada multimedia interaktif, yaitu perbaikan terkait pengertian kesehatan mulut menjadi kesehatan gigi secara umum, perbaikan kalimat hindari menjadi "kurangi makanan yang manis dan lengket" dan contoh gambar seperti "es teh" dan "coklat" diganti yang sesuai dengan pengertian dari gambar tersebut. serta penambahan informasi tentang jenis sikat gigi dan penggunaan sikat gigi yang benar.

\section{Hasil Validasi Ahli Media}

Dalam pembuatan multimedia interaktif juga melewati tahap validasi oleh ahli media yang berkompeten di dalamnya sehingga menghasilkan media yang layak dengan hasil sebagai berikut.

Tabel 3. Penilaian Ahli Media

\begin{tabular}{lcl}
\hline Aspek & $\%$ & Keterangan \\
\hline Tampilan & $87,5 \%$ & Sangat layak \\
Teks/tipografi & $100 \%$ & Sangat layak \\
Gambar & $93,7 \%$ & Sangat layak \\
Animasi dan transisi & 91,6 & Sangat layak \\
Audio & $100 \%$ & Sangat layak \\
video & $100 \%$ & Sangat layak \\
Penggunaan & $100 \%$ & Sangat layak \\
Navigasi dan interactive link & $100 \%$ & Sangat layak \\
\hline
\end{tabular}


Ahli media juga memberikan saran untuk perbaikan multimedia interaktif yaitu penambahan watermark pada video yang diambil dari internet, dalam tahap validasi seharusnya sudah dalam bentuk final seperti kemasan, sampul, cover dalam, dan petunjuk cetak.

\section{Hasil Uji Coba Pengguna (Guru)}

Uji coba pengguna dilakukan untuk mengetahui apakah multimedia interaktif ini sesuai dengan sasaran. Dalam uji coba pengguna ini dilakukan oleh guru pengajar kelas 5 , dengan hasil sebagai berikut.

Tabel 4. Penilaian Oleh Pengguna (Guru)

\begin{tabular}{lcc}
\hline Aspek & $\%$ & Keterangan \\
\hline Media sebagai alat bantu & $85 \%$ & Sangat layak \\
Media menciptakan rasa senang & $100 \%$ & Sangat layak \\
Media membantu memahami informasi & $100 \%$ & Sangat layak \\
Petunjuk penggunaan & $100 \%$ & Sangat layak \\
Penggunaan bahasa & $75 \%$ & Layak \\
Ketepatan istilah & $85 \%$ & Sangat layak \\
Kemenarikan tampilan multimedia & $100 \%$ & Sangat layak \\
Penggunaan gambar, video, dan suara & $100 \%$ & Sangat layak \\
Multimedia dapat digunakan mandiri & $75 \%$ & Layak \\
Kemudahan dalam penggunaan & $75 \%$ & Layak \\
\hline
\end{tabular}

Pengguna juga memberikan saran perbaikan dari isi multimedia interaktif ini yaitu penambahan pengertian jenis dan fungsi gigi supaya dipaparkan serta penggunaan bahasa lebih diperhatikan lagi pada sasaran.

\section{Hasil Uji Coba Kelompok Kecil}

Hasil multimedia interaktif yang telah direvisi berdasarkan saran dari ahli media, materi dan pengguna selanjutnya diujicobakan pada 8 siswa dengan hasil sebagai berikut.

Tabel 5. Hasil uji Coba Kelompok Kecil

\begin{tabular}{lcl}
\hline \multicolumn{1}{c}{ Aspek } & $\%$ & Keterangan \\
\hline Siswa merasa senang belajar & $100 \%$ & Sangat layak \\
dengan multimedia interaktif & $94 \%$ & Sangat layak \\
Kemenarikan tampilan multimedia & $91 \%$ & Sangat layak \\
Pemahaman materi yang disajikan & $100 \%$ & Sangat layak \\
Kebermanfaatan materi & $94 \%$ & Sangat layak \\
Contoh yang disajikan terlihat jelas & $91 \%$ & Sangat layak \\
Kejelasan tulisan & $94 \%$ & Sangat layak \\
Kejelasan gambar & $94 \%$ & Sangat layak \\
Kejelasan suara & $97 \%$ & Sangat layak \\
Kejelasan video & $94 \%$ & Sangat layak \\
Pemahaman materi setelah & & \\
mendapatkan materi & &
\end{tabular}


Pada uji coba kelompok kecil siswa memberi saran agar tulisan lebih jelas atau diperbesar lagi, hal ini menyulitkan siswa ketika membaca tulisan. Namun hal ini dikarenakan faktor jarak pandang siswa yang menduduki bangku belakang jauh.

\section{Hasil Uji Coba Kelompok Besar}

Uji coba kelompok kecil ini menghasilkan multimedia interaktif yang telah dilakukan perbaikan berdasarkan saran dari siswa yang selanjutnya diuji cobakan pada 20 siswa (kelompok besar), dengan hasil sebagai berikut.

Tabel 5 Hasil Uji Coba Kelompok Besar

\begin{tabular}{lcl}
\hline \multicolumn{1}{c}{ Aspek } & $\mathbf{\%}$ & Keterangan \\
\hline Siswa merasa senang belajar & $100 \%$ & Sangat layak \\
dengan multimedia interaktif & $90 \%$ & Sangat layak \\
Kemenarikan tampilan multimedia & $86 \%$ & Sangat layak \\
Pemahaman materi yang disajikan & $98 \%$ & Sangat layak \\
Kebermanfaatan materi & $90 \%$ & Sangat layak \\
Contoh yang disajikan terlihat jelas & $90 \%$ & Sangat layak \\
Kejelasan tulisan & $92 \%$ & Sangat layak \\
Kejelasan gambar & $81 \%$ & Sangat layak \\
Kejelasan suara & $87 \%$ & Sangat layak \\
Kejelasan video & $92 \%$ & Sangat layak \\
Pemahaman materi setelah mendapatkan & & \\
materi & & \\
\hline
\end{tabular}

Pada uji coba kelompok besar sebagian besar siswa tidak memberikan saran, namun ada beberapa saran yang sama dengan uji coba sebelumnya dikarenakan jarak pandang dengan layar proyektor terbilang jauh sehingga kurangnya kejelasan tulisan.

\section{PEMBAHASAN}

Produk akhir multimedia interaktif tentang kesehatan gigi dan mulut ini telah dihasilkan melalui prosedur pengembangan yang melalui beberapa proses. Proses tersebut dimulai dari analisis kebutuhan, validasi ahli, dan uji coba hingga memperoleh hasil produk akhir multimedia interaktif yang siap diguna-kan. Multimedia interaktif ini sangat sesuai dengan sasaran karena disusun berdasarkan kebutuhan spesifikasi yang diinginkan siswa baik dari kebermanfaatan materi, tampilan media, serta sumber belajar siswa.

Komala (2014) menyatakan media promosi kesehatan yang baik adalah yang mampu memberikan informasi atau pesan kesehatan yang sesuai dengan tingkat penerimaan sasaran sehingga sasaran mampu mengubah perilaku yang sesuai dengan pesan yang disampaikan. Multimedia interaktif sangat tepat digunakan sebagai media promosi kesehatan pada sasaran mengingat belum tersedianya media yang serupa baik dalam pembelajaran maupun penyu-luhan kesehatan. Selain itu penggunaan multimedia khususnya media pembelajaran di sekolah bertujuan untuk menda-patkan pembelajaran yang efisien dan efektif (Dwiyogo, 2013).

Pertimbangan lainnya yaitu multimedia interaktif tidak didasarkan atas kesenangan pribadi (Suiraoka, 2012). Dalam hal ini peneliti melakukan analisis kebutuhan spesifikasi media yang diharapkan oleh siswa. Selain itu multimedia interaktif ini juga melalui bebe-rapa tahap validasi seperti validasi oleh ahli materi, ahli media, pengguna (guru), dan juga siswa sebagai bahan perbaikan media.

Peneliti juga menyadari bahwa multimedia interaktif ini memiliki kelebihan dan kekurangan, sehingga tidak dapat dikatakan tidak semua media 
dapat dipakai untuk semua tujuan (Suiraoka, 2012). Multimedia interaktif ini memiliki kelebihan multimedia ini dapat dijalankan di berbagai jenis komputer, karena dalam penelitian ini peneliti merancang multimedia menggunakan aplikasi Autoplay Media Studio maka bagi pengguna lainnya tidak perlu meng-instalasi aplikasi terlebih dahulu untuk mengoperasikannya, namun multimedia interaktif berbasis Autoplay ini langsung bisa dijalankan.

Selain itu peneliti juga menyadari bahwa dalam pembuatan multimedia ini peneliti memiliki keterbatasan dikarenakan dari kelemahan aplikasi Autoplay, diantaranya tampilan template yang sangat minim, ketersediaan transisi per-gantian slide sangat kurang sehingga dalam multimedia ini kurang bervariasi baik dari transisi dan juga tampilan template (Kistatuhu, 2014).

Aspek selanjutnya yaitu dari kesesuaian materi dengan media (Suiraoka. 2012). Pada aspek materi yang disampaikan terdiri dari pengertian ke-sehatan gigi dan mulut dimana pada awal tampilan media disuguhkan dengan pemutaran video kartun animasi tentang aktivitas gigi. Kemudian dilanjutkan dengan jenis dan fungsi gigi dan selanjutnya menyampaikan tentang penyakit gigi dan mulut dengan memberikan tampilan gambar akibat kerusakan gigi. Selanjutnya pada tahap akhir peneliti meberikan sebuah quiz interaktif guna mengulas kembali materi yang sudah didapatkan oleh siswa.

Pertimbangan pemilihan media selanjutnya yaitu disesuaikan dengan aspek kondisi lingkungan (Suiraoka, 2012). Dalam hal ini multimedia interaktif sangat tepat digunakan sebagai media promosi kesehatan dengan kondisi lingkungan sasaran mengingat kondisi sarana dan prasarana sangat mendu-kung untuk penggunaan multimedia interaktif. Selain itu beberapa guru sudah ada yang menerapkan pembelajaran menggunakan media pembelajaran interaktif.

Multimedia interaktif ini juga didasarkan atas tingkat kemampuan sasaran (Suiraoka, 2012). Peneliti juga mengacu dari penelitian yang dilakukan oleh Muin (2014) bahwa pada usia anak 10-12 tahun yang rata-rata duduk di bangku kelas 5 dianjurkan untuk dilakukan pendidikan tentang kesehatan gigi dan mulut. Selain itu penelitian lain menyebutkan bahwa penyampaian materi menggunakan multimedia interaktif dapat meningkatkan pemahaman materi yang disampaikan dibandingkan dengan pembelajaran secara konvensional (Rizqi, 2015).

Dalam pengembangan produk multimedia interaktif ini ada beberapa tools atau software pendukung lainnya sehingga terciptanya produk tersebut. Aplikasi pertama yaitu Autoplay Media Studio itu sendiri merupakan aplikasi pengolah utama sebagai area kerja peneliti dalam mengintegrasikan berbagai media lainnya (Dwiyogo, 2013). Selanjutnya didukung dengan aplikasi Adobe Photoshop CS4 dan CorelDraw $X 4$ sebagai salah satu aplikasi pengolah gambar baik dalam pengukuran gambar dan memanipulasi gambar serta dalam pembuatan buku pedoman petunjuknya. Selain itu dalam proses pengeditan video dan suara peneliti menggunakan Sony Vegas Pro dalam pengembangan produknya.

Tujuan dari pengembangan multimedia interaktif sebagai media promosi kesehatan tentang kesehatan

gigi dan mulut adalah untuk menghasilkan media yang mampu meningkatkan pengetahuan sasaran yang membacanya. Maka dari itu multimedia interaktif berisikan materi penting terkait masalah tersebut. Adapun materi yang ada dalam multimedia interaktif adalah pengertian kesehatan gigi dan mulut, jenis dan fungsi gigi, penyakit 
akibat gigi dan mulut, penyebab kerusakan gigi, upaya memelihara kesehatan gigi dan mulut, ma-kanan yang mampu merusak gigi, cara menyikat gigi yang benar. Materi yang disajikan dalam multimedia interaktif ini berdasarkan buku dan beberapa jurnal yang telah dikatakan layak oleh ahli materi. Penyajian tulisan yang ditampilkan dalam materi menginterpretasikan gambar dan pemikiran yang sederhana serta materi disajikan secara mengalir yang artinya siswa akan mengikutinya dengan mudah hal ini membuat media sangat efektif (Dwiyogo, 2013). Selain itu penilaian ahli materi terkait dengan materi dalam multimedia ini menunjukkan hasil yang sangat baik dengan kategori sangat layak pada setiap aspek penilaian.

Multimedia interaktif tentang kesehatan gigi dan mulut ini mampu memberikan pesan yang sangat kuat kepada sasaran, sebab dalam tampilan multimedia interaktif ini terdapat video pesan kesehatan tentang kesehatan gigi dan mulut dimana kemampuan menampilkan video untuk berkomunikasi dengan siswa sangatlah efektif (Dwiyogo, 2013).

Melalui multimedia interaktif ini diharapkan siswa dapat mengingat materi yang disampaikan oleh penyuluh dibantu dengan video, gambar dan suara yang menarik pula untuk diingat serta didukung kemampuan kognitif siswa dalam berpikir, berperilaku, dan merubah kebiasaan hidup sehat melalui media yang disampaikan (Khadijah, 2016).

Multimedia interaktif ini dikembangkan sesuai dengan tahap kognitif siswa kelas 5 sekolah dasar yang sudah mampu mengenali suatu objek, mencari hubungan timbal balik beberapa hal, dan pada tahap ini siswa sudah memperkirakan apa yang akan terjadi selanjutnya serta dapat mengambil kesimpulan dari suatu pernyataan (Sunarto, 2008). Multimedia interaktif yang ditampilkan menampilkan audio, visual, dan animasi yang sesuai dengan

materi, teks dalam materi mengiterpretasikan gambar dan pemikiran yang sederhana, tampilan yang mengalir, membeikan musik, gambar, dan video dapat menghindari kebosanan siswa dan belajar yang efektif (Dwiyogo, 2013).

\section{KESIMPULAN}

Berdasarkan analisis pembahasan dan juga hasil kegiatan validasi ahli media, ahli materi, dan pengguna (guru), serta hasil uji coba maka dapat dikatakan bahwa multimedia interaktif tentang kesehatan gigi dan mulut ini sangat layak untuk digunakan sebagai media promosi kesehatan pada siswa kelas 5 SDN Percobaan 02 Kota Malang. Meskipun demikian multimedia ini memiliki kelemahan yang sudah disebutkan di atas. Selain itu kelemahan lainnya adalah belum diketahui seberapa besar pengaruh multimedia interaktif ini terhadap peningkatan pengetahuan dan efektivitas multimedia itu sendiri.

\section{SARAN}

Peneliti memberikan saran berupa dalam upaya pemanfaatan, diseminasi dan pengembangan produk lebih lanjut untuk multimedia interaktif ini agar dapat disempurnakan menjadi media yang lebih baik. Berikut ini adalah saran dari peneliti terkait tiga hal tersebut:

\section{Saran Pemanfaatan}

Multimedia interaktif ini dapat dimanfaatkan dalam kegiatan promosi kesehatan melalui kegiatan penyuluhan maupun sebagai sumber belajar siswa secara mandiri. Melalui kegiatan penyuluhan multimedia interaktif dapat langsung dioperasikan langsung oleh sasaran dengan catatan tersedianya komputer atau laptop yang mumpuni sebelum kegiatan penyuluhan berlangsung. Selain itu sebelum mengoperasi-kan multimedia interaktif 
pengguna perlu memberikan atau membacakan panduan penggunaan multimedia agar sasaran mampu mengerti dan mudah menggunakannya. Multimedia ini juga bisa dibagikan setelah pengguna melakukan kegiatan penyuluhan sebagai sa-rana dan sumber belajar mandiri siswa. Selain itu peneliti menghimbau kepada pengguna (petugas penyuluh, guru, orang tua) agar mendampingi siswa saat menggunakan agar tidak menyalahgunakan komputer atau laptop yang sedang dijalankan.

\section{Saran Diseminasi}

Penyebarluasan informasi sangatlah penting dilakukan. Multimedia ini dapat digunakan sebagai sarana informasi bagi semua petugas promosi kesehatan, sekolah, dan lembaga lainnya yang membutuhkan terkait kesehatan gigi dan mulut, namun peneliti memberikan saran yang harus diperhatikan sebelum multimedia interaktif ini disebarluaskan dan digunakan yaitu: a) pemilihan sasaran dalam penyebarluasan perlu didasarkan pada analisis kebutuhan dan karakteristik siswa untuk memastikan sasaran benar-benar membutuhkan multimedia interaktif tentang kesehatan gigi dan mulut, b) multimedia interaktif sebagai media promosi kesehatan dapat disebar-luaskan kepada pengguna (petugas kese-hatan, guru, orang tua) sebagai sasaran sekunder yang dapat menggunakannya sebagai media informasi terkait kesehatan gigi dan mulut, c) penyebarluasan multimedia interaktif juga dapat dilakukan melalui website yang terdaftar dan terverifikasi sehingga mudah didapatkan, d) diperlukan sosialiasi terkait penggunaan multimedia interaktif kepada pihak terkait sehingga mulitimedia ini dapat digunakan dengan tepat.

\section{Saran Pengembangan Produk Lebih Lanjut}

Peneliti memberikan saran lebih lanjut kepada peneliti berikutnya supaya multimedia ini mengalami penyempurnaan melalu pengembangan produk lebih lanjut. Berikut adalah saran yang diberikan oleh peneliti: a) multimedia interaktif tentang kesehatan gigi dan mulut ini belum diketahui seberapa besar pengaruh terhadap

peningkatan pe-ngetahuan siswa. Berdasarkan hal tersebut diperlukan penelitian lebih lanjut terkait pengaruh multimedia interaktif tentang kesehatan gigi dan mulut terhadap pengetahuan siswa, b) penelitian lanjutan terkait efektivitas multimedia interaktif dalam meningkatkan pengetahuan siswa tentang kesehatan gigi dan mulut jika dibandingkan dengan jenis media lain juga perlu dilakukan, c) penambahan grafik/animasi bergerak untuk menambah daya tarik media, d) multimedia interaktif dapat dioperasikan melalui komputer atau laptop, harapannya multimedia media ini dapat dioperasikan melalui smartphone seperi Android dan Iphone yang tersedia di plyastore sehingga mudah didapatkan dan dapat menjadi sumber belajar dimanapun dan kapanpun, e) sasaran penelitian selanjutnya diharapkan lebih luas sehingga manfaat multimedia interaktif ini dapat dirasakan pula oleh sasaran yang lebih banyak.

\section{DAFTAR RUJUKAN}

Azizi M. Rahman. 2015. Pengaruh Penggunaan Multimedia Interaktif Terhadap Aktivitas dan Hasil Belajar Siswa pada Materi Peredaran Darah Manusia. Skripsi. Lampung: Universitas Lampung.

Andriany P., Cut Fera N., Summiyati A. 2016. Perbandingan Efektifitas Media Penyuluhan Poster Dan Kartun Animasi Terhadap Pengetahuan kesehatan Gigi Dan Mulut. Jurnal Syiah Kuala Dentistry Society, 1 (1): 66-72. 
Darmawan, L. 2007. Cara Instan Membuat Gigi Sehat \& Cantik Dengan Dental Cosmetics. Jakarta: PT Gramedia Pustaka

Dwiyogo, W.D. 2013. Media Pembelajaran. Malang: Wineka Media

Gayatri, R.W dan Mardianto. 2016. Gambaran Status Karies Gigi Anak Sekolah Dasar Kota Malang. Jurnal Preventia, 1 (1): 38-45.

Hidayah. N. 2012. Perbedaan Perkembangan Kognitif Anak Kelas II SD Ditinjau Dari Sistem Pembelajaran Full Day School dan Half Day School. Skripsi. Semarang: UIN Walisongo Semarang.

Khadijah. 2016. Perkembangan Kognitif Anak Usia Dini. Medan: Perdana Publishing

Khotimah, B.N. 2015. Efektivitas Penyuluhan Dengan Kartu Kuartet Berbasis Multimedia Terhadap Pengetahuan Kesehatan Gigi Dan Mulut Pada Usia 8-10 Tahun. Skripsi. Jember: Universitas Jember.

Kistatuhu, Nurul W. 2014. Penggunaan Media Program Autoplay Untuk Meningkatkan Hasil Belajar Dan Motivasi Siswa Kelas VII MTs Negeri Ngantru Pada Materi Garis Dan Sudut. Skripsi. Tulungagung: IAIN Tulungagung.

Komala L., Evi N., Priyo S. 2014. Strategi Pemilihan Media Promosi Kesehatan Dalam Penanggulangan Hiv/Aids Di Kabupaten Garut. Jurnal Ilmu Komunikasi, Vol 10 (2): 34-43.

Larasati, R. 2012. Hubungan Kebersihan Mulut Dan Penyakit Sistemik Dan Usia Harapan Hidup. Jurnal Skala Husada, 9 (1): 97-104.

Malik, I. 2008. Kesehatan Gigi Dan Mulut. Makalah dibawakan pada Ceramah di Badan Pengembangan Sistem Informasi dan Telematika Jawa Barat, dalam situs: (http://repo sitory.unpad.ac.id/).

Mofidi. M., Leslie P.Z., R. Gary R. 2009. Oral Health of Early Head
Start Children: A Qualitative Study of Staff, Parents, adn Pregnant Women. Research and Practice, 99 (2): 245-251.

Notoatmodjo, S. 2012. Promosi Kesehatan dan Perilaku Kesehatan. Jakarta: PT. Rineka Cipta.

Pratiwi D.A., Nani Y., Putu Eka M.E. 2016. Pengaruh Penyuluhan Metode Permainan Edukatif Dan Metode Ceramah Terhadap Pengetahuan, Sikap Dan Tindakan Tentang Pencegahan Penyakit Diare Pada Murid SD Di Kecamatan Poasia Kota Kendari Tahun 2015. Jurnal Ilmiah Mahasiswa Kesehatan Masyarakat, 1 (2): 1-12.

Putra. W., Khairuddin., Ashabul K. 2016. Pengembangan Media Pembelajaran Interaktif pada Mata Pelajaran Komposisi Foto Digital dengan Software Autoplay Media Studio di SMK N 2 Pariaman. Jurnal Faculty of Education, 2 (2): 1-12.

Rizqi, M.B. 2015. Pengembangan Media Pembelajaran Autoplay dan Quiz Creator Pada Mata Pelajaran IPS Materi Penjajahan Belanda Untuk Kelas V SD/MI Di SDI AlFaqih Sukoanyar Pakis Malang. Skripsi. Malang: Universitas Negeri Maulana Malik Ibrahim

Sugiyono. 2014. Metode Penelitian Kuantitatif, Kualitatif, dan $R \& D$. Bandung: Alfabeta

Sunarto. 2008. Perkembangan Peserta Didik. Jakarta: Rineka Cipta.

Widalatika. 2014. Pengembangan Media Visual Kirigami Pop Up Dengan Materi Potensi Dan Sebaran Sumber Daya Alam Indonesia Untuk Pembelajaran IPS di SMP Kelas VII. Skripsi. Yogyakarta: Universitas Negeri Yogyakarta,

Suiraoka, I.P., dan I Dewa N.P. 2012. Media Pendidikan Kesehatan. Yogyakarta: Graha Ilmu. 